\title{
TITLE:
}

\section{Reports from the Field: Mahale, Tanzania : Invasive Plant in Chimpanzee Habitat at Mahale}

$\operatorname{AUTHOR}(\mathrm{S})$ :

\section{CITATION:}

Reports from the Field: Mahale, Tanzania: Invasive Plant in

Chimpanzee Habitat at Mahale. Pan Africa News 1996, 3(1): 5-5

ISSUE DATE:

1996-06

URL:

http://hdl.handle.net/2433/143335

\section{RIGHT:}

Copyright (C) Pan Africa News. 


\section{Invasive Plant in Chimpanzee Habitat at Mahale}

Linda A. Turner

Kyoto University

Approaching the Mahale Mountains National Park in western Tanzania from a boat on Lake Tanganyika, the contrast between the deforested hillsides to the north of the park boundary and the green sweep of forest on the western slopes of the mountains to the south is remarkable. Also remarkable are the dense, shady groves of a small, slim tree which crowd down to the lakeshore and whose crowns are covered in the rainy season with striking displays of golden-yellow flowers. Unfortunately this prolific and attractive tree is unwanted. Senna spectabilis DC (Irwin \& Barneby), a native of tropical America which was introduced to Mahale in 1967 as a source of shade, has become completely naturalized in the park and for the past several years has been perceived as a threat to the regeneration of local plant communities, due to its apparent ability to dominate native flora.

When $S$. spectabilis was introduced to the Kasoje area of what is now the Mahale Mountains National Park, most of the lowland primary forest had been destroyed due to a long history of slash-andburn cultivation. The forests at Mahale have been in the process of regeneration for about two decades now, but unfortunately areas of Kasoje, which were probably once covered with wooded grassland and coastal forest, are now dominated by the exotic species. $S$. spectabilis has proved an aggressive colonizer of open land and continues to spread in the lowland area. The tree has shown resistance to efforts at control through cutting and girdling: in 1991 the Park Warden ordered that all trees in the vicinity of the Kansyana research camp (about $1 \mathrm{~km}$ inland from the lakeshore) and the worker's village of Kasiha be cut down but the trees quickly regrew. Moreover, chimpanzees which use the lowland forests have not been observed to eat any part of this species and preliminary investigation suggests it is of little use to other wildlife.

Study of the density, distribution and ecology of S. spectabilis has been underway since July 1994 as part of a larger investigation of chimpanzee habitat use at Mahale. Mr. C.K. Ruffo, a Tanzanian botanist with the National Tree Seed Programme in Morogoro, visited Mahale for three days in February, 1995 at the invitation of Tanzania National Parks management to positively identify the exotic species, conduct some preliminary investigations regarding its invasion and make suggestions for its control. Future multidisciplinary research into the tree's ecology and effect on wildlife is planned with colleagues in Japan, Canada and Tanzania.

$S$. spectabilis certainly merits further study. Early analysis has shown it to be equipped with an impressive chemical arsenal: parts of the tree were found to contain an allelochemical which may inhibit the growth of other species, an enzyme which interferes with protein digestion, an insecticide and medicinal compounds including an antischistosomal agent. The tree appears to have antimalarial properties as well.

To the human inhabitants of the Mahale of the past, $S$. spectabilis was an excellent source of shade, firewood and building material as well as crop protection due to its ability to form living fences. Now, however, the unchecked spread of this species has serious implications for wildlife conservation and tourism due to its apparent lack of utilization by most animals, especially the chimpanzees (Pan troglodytes schweinfurthii) which the park was established to protect. A thorough understanding of the ecology of $S$. spectabilis and implementation of management strategies for its control are required if further disruption of the native biota at Mahale is to be avoided.

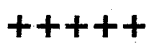

